Indexed by

Scopus

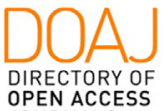

OPEN ACCESS

JOURNALS

Crossref

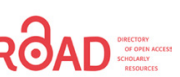

KOBSON

81 Google

\title{
INVESTIGATION OF POTENTIAL LANDSLIDES DUE TO LIQUEFACTION ON THE BALAROA ROAD SECTION USING THE LIMIT EQUILIBRIUM METHOD
}

\section{Sriyati Ramadhani}

Tadulako University, Department of Civil Engineering,

Palu, Indonesia

\section{Martini}

Tadulako University, Department of Civil Engineering, Palu, Indonesia

\author{
Mastura Labombang \\ Tadulako University, Depart- \\ ment of Civil Engineering, \\ Palu, Indonesia
}

\section{Shafira Yuniar Anwar}

Tadulako University, Department of Civil Engineering,

Palu, Indonesia

Key words: landslide, liquefaction, Balaroa road section, limit equilibrium method doi:10.5937/jaes0-28853

Cite article:

Ramadhani, S., Martini, Labmbang, M., Anwar, S. Y. (2021) INVESTIGATION OF POTENTIAL LANDSLIDES DUE TO LIQUEFACTION ON THE BALAROA ROAD SECTION USING THE LIMIT EQUILIBRIUM METHOD, Journal of Applied Engieering Science, 19(3) 556-563, DOI:10.5937/ jaes0-28853

Online aceess of full paper is available at: www.engineeringscience.rs/browse-issues 


\title{
INVESTIGATION OF POTENTIAL LANDSLIDES DUE TO LIQUEFACTION ON THE BALAROA ROAD SECTION USING THE LIMIT EQUILIBRIUM METHOD
}

\author{
Sriyati Ramadhani*, Martini, Mastura Labombang, Shafira Yuniar Anwar \\ Tadulako University, Department of Civil Engineering, Palu, Indonesia
}

The earthquake on September 28, 2018 in Palu city triggered liquefaction. The liquefaction affected several areas, including Balaroa. Some parts in Balaroa experienced landslide such as the road section which formed the slope. The purpose of this study was to identify the potential of landslides due to liquefaction in Balaroa road section based on numerical modeling using the limit equalibrium method. This study was conducted in Balaroa, West Palu sub district, Palu City, Central Sulawesi Province. The slope stability analysis modelled three locations prone to landslides using the limit equalibrium method assisted by Slide 7.0 program. The results showed the safety factor value of hose three locations in Balora road section using methods of Ordinary, Bishop and Janbu was FS $<1$. It indicated that the slope is in unsafe condition and vulnerable to lanslides, therefore the government should take this study into consideration.

Key words: landslide, liquefaction, Balaroa road section, limit equilibrium method

\section{INTRODUCTION}

Land mass movement or landslide is one of the most common natural disaster in Indonesia, specifically in Central Sulawesi province including Palu City. The landslide hazard level of Palu City is in the high category with a score of 23.7 [1]. The occurence of landslides are usually caused by several factors including high rainfall, human activities such as the construction of houses by cutting slope foot, earthquake seismic activity, weathering of rocks, etc. The landslide impacts on human life and the environment, such as loss of life and material as well as causes severance to economic and developing activities around the disaster area.

Balaroa is a village located in West Palu sub district. In 2018, the total population was 14.779 and the total width was $2.38 \mathrm{Km}^{2}$ [2]. Topographically, Balaroa consists of $85 \%$ plains and $15 \%$ hills, hence it is considered as a

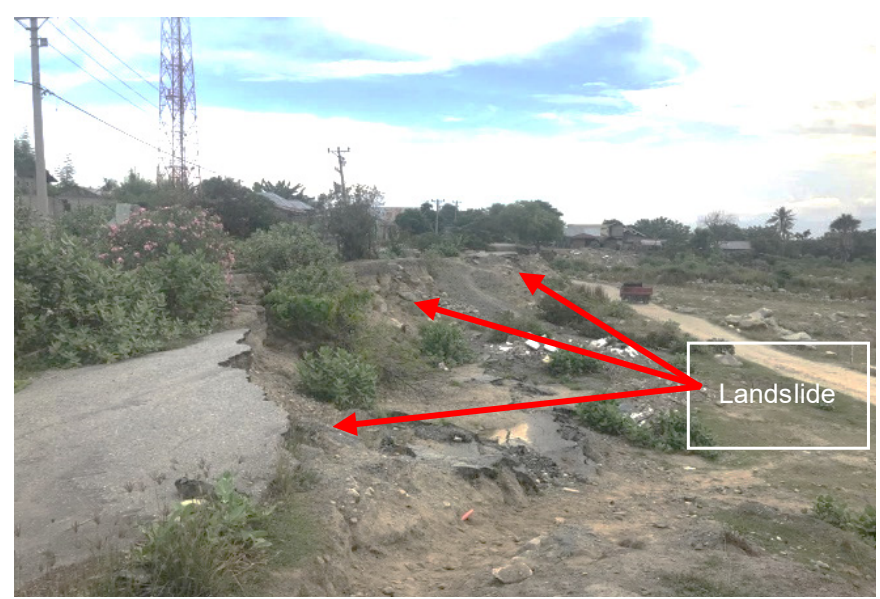

(a) densely populated area. The 7.4 SR earthquake on September 28th, 2018, struck Balaroa and caused the occurence of liquefaction. The liquefaction then triggered landslides on the road section of Balaroa as showed in Figure 1. The road section is located on a hilly topography, hence the landslide forms an increasingly steeper slope which has a very high level of vulnerability of landslide hazards.

The landslide occurred in Balaroa was different from other locations since it has steeper slopes. The landslides covered the area about $0.4 \mathrm{~km}^{2}$ width and $980 \mathrm{~m}$ length. The landslide area was a high density settlement as showed in figure 1 before the liquefaction and figure 2 after the liquefaction [3].

The Balaroa road section is an alternative road connecting Palu City with Donggala Regency (Figure 1.a) and

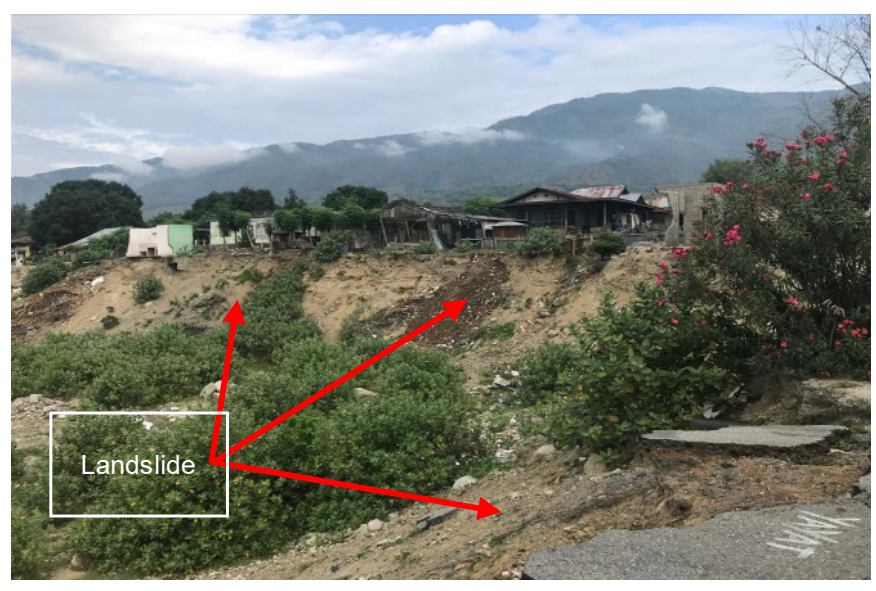

(b)

Figure 1: Landslide on the Balaroa road section due to the 28th September 2018 earthquake. a) Palu City alternative road to Donggala regency and b) Palu City alternative road to Sigi regency. 


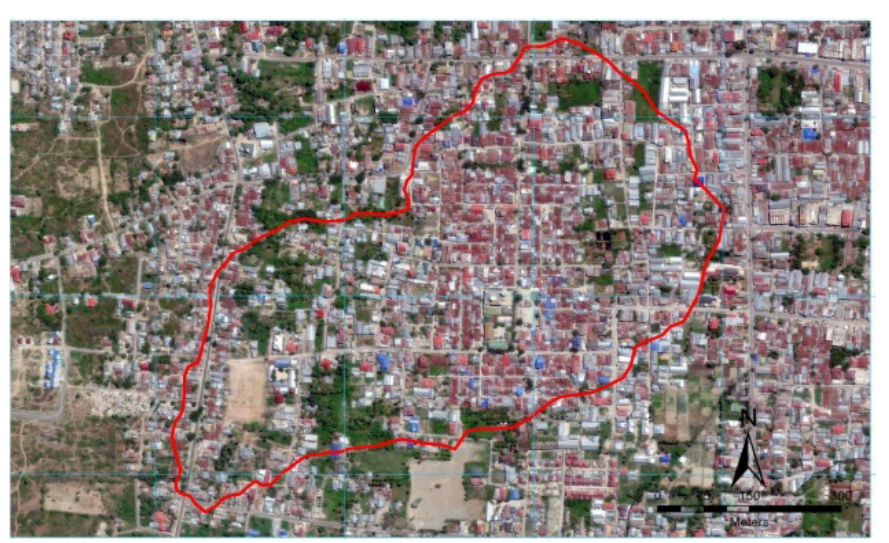

(a)

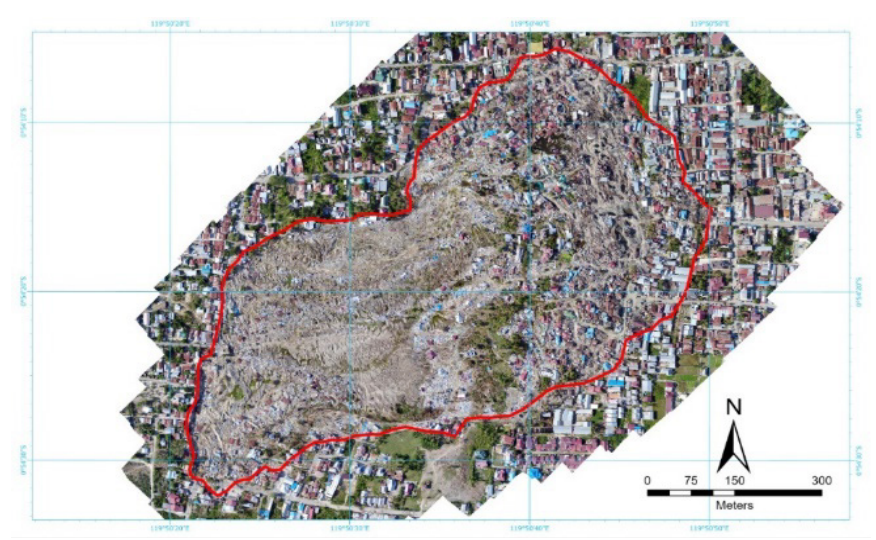

(b)

Figure 2: Balaroa sub district map. a) before liquefaction and b) after liquefaction [3]

Palu City with Sigi Regency (Figure 1.b). There are still many buildings on top of the slopes that formed due to liquefaction including residential houses, schools and offices such as Balaroa village office. The condition of slope illustrates that if the slope is unstable it would threaten the people safety and their settlements as well. As it is well known that Balaroa is an area where the Palu Koro fault passes and it is considered as a red zone area (ZRB 4) based on Disaster Prone Areas map [4].

Based on the topography, geology, and seismology conditions, Palu City area have the potential to suffer damage due to earthquakes including secondary disasters such as tsunami, liquefaction and cliff landslides, as the previous 7.6 SR earthquake had occured on May 20th, 1938, its vibrations were experienced throughout Sulawesi Island [5]. The geological and morphological conditions of a very dense area will affect the liquefaction hazard [6].

Slope instability occurs due to high and steep slopes, geological and topographic conditions such as cutting underground slopes and the presence of weak layers as well [7]. If the slope is unstable, it will threaten the safety of human life and the surrounding buildings. Slope cutting will cause a large change in forces on the slope which in the end results in disruption of slope stability [8].

Considering the previous problems, it is significant to conduct a study of slope stablitiy on the Balaroa road section since this area considered as a densely populated residential area. Slope stability was analysed by the limit equalibrium method using the Slide program. The purpose of this study was to investigate the potential landslaides due to liquefaction on th Balaroa road section using the limit equalibrium method.

\section{The geological conditions of Palu City}

Based on the engineering geology analysis [9], Palu City had several rock formations composing this area:

1. Alluvium and coastal sediment (Qap): Consisting of gravel, sand, mud and coral limestone. In areas formed by alluvium deposits, the soil layer generally contains of sand at the top, silt in the middle and loam at the bottom. The sand is gray, loose, good porosity, good permeability with a thickness of $1-7.2 \mathrm{~m}$, silt is found under gray brown sand, soft - firm, medium plasticity with a thickness of $0.2-0.7 \mathrm{~m}$, while the clay is brown - dark brown, soft - firm, high plasticity with varying thickness between $0.1-2.7 \mathrm{~m}$. The depth of the groundwater level ranges from $0.5-16 \mathrm{~m}$ below the ground level. The groundwater level around the crown of the soil movement is about more than 13 $\mathrm{m}$ below the ground level while at the boundary with swampy sediment it is about $6 \mathrm{~m}$ below the ground level. The groundwater bordering swampy deposits is predicted in a confined aquifer zone. The water at this location is artesian, so from this point, it has a relatively high pore water pressuring up to the foot of the slope in Balaroa housing which is only about 1.5 $\mathrm{m}$ below ground level.

The results of laboratory analysis [9] indicated that sand soil has a specific gravity of $2.682-2.770$, a unit weight of $1.494-1.868 \mathrm{gr} / \mathrm{cm}^{3}$, a moisture content of $4.78 \%$ $18.99 \%$, the symbol group is SW, SM , SC, SP, the cohesion value is $0.000-0.100 \mathrm{~kg} / \mathrm{cm}^{2}$ and the friction angle value is $22.90^{\circ}-39.38^{\circ}$. Laboratory analysis results for silt soil have specific gravity of 2.697-2.773, a unit weight of $1.578-1.902 \mathrm{gr} / \mathrm{cm}^{3}$, a moisture content of $4.34 \%-$ $36.71 \%$, symbol group ML, MH, cohesion value of 0.000 $0.152 \mathrm{~kg} / \mathrm{cm}^{2}$ and the friction angle is $21.94^{\circ}-40.03^{\circ}$. The results of laboratory analysis for clay soil have a specific gravity of 2.687-2.777, a unit weight of $1.500-1.950 \mathrm{gr} /$ $\mathrm{cm}^{3}$, a moisture content of $9.98 \%-27.79 \%$, the symbol group CL, the cohesion value of $0.044-0.173 \mathrm{~kg} / \mathrm{cm}^{2}$ and the friction angle of $21.94^{\circ}-28.47^{\circ}$.

2. Molasa Celebes Serasin and Serasin (QTms): These rocks are found at a lower altitude on the sides of the two bunds, overlapping the Tinombo Formation and the metamorphic rock complex at a lower altitude, containing rubble originating from the older formation consisting of conglomerates, sandstones, mudstones, coral limestones, and marl, in this case, they all are only weakly hardened.

The research [9] predicted that the liquefaction in Palu City seemed highly probable, due to its rock formations and the 
position of the city which has high intensity earthquake.

\section{The limit equilibrium method}

The limit equalibrium method was applied for analysing inhomogeneous materials. The calculation of the slope safety factor value is based on the integration of forces acting on each slice. Some of the most frequently methods applying this principle including the modified Bishop which is suitable for circular landslides and Janbu method which is suitable for both circular and noncircular landslides, polygonal, and planar [10]. The modeling techniques of the limit equalibrium method is based on the static style and time equalibrium [11].

The slope stability analysis based on the limit equalibrium method was carried out by dividing the sloping soil masses into slices which are considered as a unique shear block [12] as shown in Figure 3.

The next calculation applied in this method was the analysis of forces that work on each slice. The calculated forces can be in the form of horizontal or vertical forces including those are due to dynamic loads that work on each slice as can be depicted in Figure 4.

Considering these forces, several formules were obtained to calculate the safety factor of a slope. The next calculation applied in this method was the analysis of forces that work on each slice as ilustrated in Table 1.

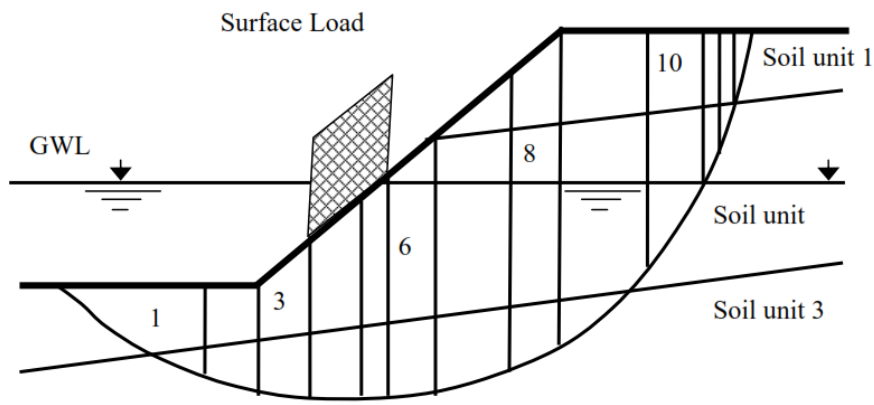

Failure Surface

Figure 3: Dividing the derailed soil mass [12]

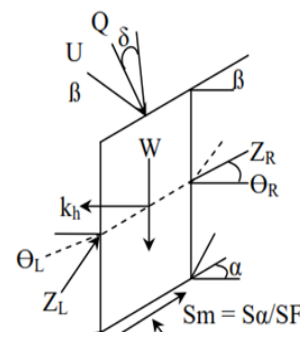

$\theta_{\mathrm{L}}$

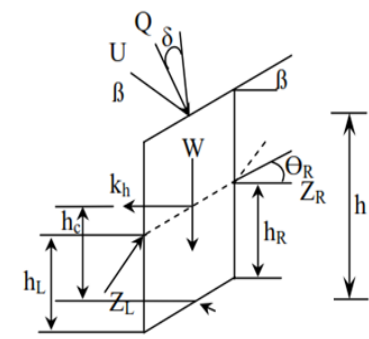

Failure Plane

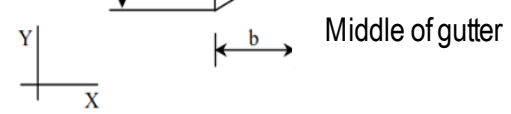

Figure 4: Forces working on each slice [12]

\section{Safety factor}

The safety factor is defined as the facctor by which the shear strength parameter can be reduced to bring slope or dam foundation into equalibrium [13]. The safety factor for a design of various rock types in engineering problems ranging from safety factor values greater than 1 for extrim loading, seismic and gravity analysis to dam design, the safety factor value was greater 1.5 , for permanent rock slopes (Table 2) and the safety factor value is greater than 2 for the fall-out block in the tunnel [13].

Table 2: Safety factor criterion [13]

\begin{tabular}{|c|c|}
\hline Safety Factor (SF) & Occurence \\
\hline $\mathrm{F}<1$ & Collapse \\
\hline $1 \leq \mathrm{F}<1.5$ & $\begin{array}{c}\text { A critical condition (not signifi- } \\
\text { cant in design) }\end{array}$ \\
\hline $\mathrm{F} \geq 1.5$ & $\begin{array}{c}\text { Stabel condition (the design } \\
\text { above the critical value) }\end{array}$ \\
\hline
\end{tabular}

The limit equilibrium method using seismic force was represented in the pseudostatic model. The seismic coefficient used is the peak ground acceleration (PGA) with the minimum safety factor to earthquake (SF>1,0) [14].

\section{Earthquake effect on slope stability}

Earthquake is one of the factors affecting slope stability.

Table 1: Static equalibrium conditions satisfied by the limit equilibrium method [12]

\begin{tabular}{|c|c|c|c|}
\hline \multirow{2}{*}{ Method } & \multicolumn{2}{|c|}{ Force Equalibrium } & \multirow{2}{*}{ Moment Equalibrium } \\
\cline { 2 - 3 } & Direction X & Direction Y & Yes \\
\hline Ordinary method of slice & No & No & Yes \\
\hline Bhisop's simplified & Yes & No & No \\
\hline Janbu's simplified & Yes & Yes & No \\
\hline Corps of Engineering & Yes & Yes & No \\
\hline Lowe and karafiath & Yes & Yes & Yes \\
\hline Janbu's generalized & Yes & Yes & Yes \\
\hline Bhisop's rigourus & Yes & Yes & Yes \\
\hline Spencer's & Yes & Yes & Yes \\
\hline Sarma's & Yes & Yes & \multicolumn{2}{c}{} \\
\hline Morgenstren - Price & Yes & & \\
\hline
\end{tabular}


[15] Slope failure caused by an earthquake usually has several characteristics including an initial hardness and high velocity.

Shear stress occurs on the rock slope due to the dynamic load of the earthquake and the influence of the increase in shear stress occurs on the soil surface from the middle of the slope to the slope foot with an extension to the inside of the slope [16]. Slope failure due to an earthquake usually has several characteristics including wide distribution,large number and high velocity [17]. [18] The Wenchuan earthquake has caused thousands of seismic landslides.

\section{RESEARCH METHOD}

In this study, a location survey was conducted to determine the slopes geometry and the soil sampling. Soil samples were taken to test the technical properties of the soil, including the physical and mechanical, in the laboratory. Location survey data and laboratory test results were then analyzed based on the limit equilibrium method with the assistance of Slide 7.0. The limit equilibrium method applied the concept of the safety factor value (SF) in analyzing the modeling of 3 (three) points of existing slope conditions that are prone to landslides. The three location points can be seen in Figure 5 with coordinates $0^{\circ} 54^{\prime} 21.3516^{\prime \prime} \mathrm{SL}$ and $119^{\circ} 50^{\prime} 23.136^{\prime \prime}$ EL for location 1, coordinates $0^{\circ} 54^{\prime} 24.066^{\prime \prime} \mathrm{SL}$ and $119^{\circ} 50^{\prime} 22.7832^{\prime \prime}$ EL for location 2 and coordinates $0^{\circ} 54^{\prime} 23.9544^{\prime \prime} \mathrm{SL}$ and $119^{\circ} 50^{\prime} 20.58$ "EL for location 3.
The value of the safe factor in slope modeling is determined by using the Ordinary method, the Bishop Simplified method and the Janbu method [19]. The type of surface failure used in this study was circular with the material model using the failure criteria of Mohr Coulomb. Factors that influence liquefaction include high earthquake intensity and groundwater levels. The research area is prone to earthquake, so in analyzing the earthquake load is included based on the peak acceleration map in the bedrock (SB) for a probability of being exceeded by $10 \%$ in 50 years being in the PGA value zone 0.6- $0.7 \mathrm{~g}$ [20], hence, the coefficient horizontal seismic determined 0.5 of the horizontal peak acceleration by determining the site class and amplification factor. The location of the study is in the rock site class (SB) wtih the amplification factor for a period of 1 second is 1.0 , so the seismic coefficient used in this study is $1 \times 0.5 \times 0.6=0.3$ [14]. The groundwater level is located at a depth of $2 \mathrm{~m}$ from the ground at the foot of the slope, therefore it is assumed in analysis that the groundwater level is at a depth of $2 \mathrm{~m}$.

Overall, based on the results from field observations and laboratory tests, the soil layers in Balaroa area are dominated by sand layers. The soil density found in the field for the three locations is very loose at a depth of $0-0.2 \mathrm{~m}$ with a qc value of $20 \mathrm{~kg} / \mathrm{cm}^{2}$, loose at a depth of $0.2-0.4 \mathrm{~m}$ with a qc value of $20-40 \mathrm{~kg} / \mathrm{cm}^{2}$, semi-loose at a depth of $0.4-$ $1.6 \mathrm{~m}$ with a qc value of $40-120 \mathrm{~kg} / \mathrm{cm}^{2}$ and solid at a depth of $1.6-3 \mathrm{~m}$ with a qc value of $120-200 \mathrm{~kg} / \mathrm{cm}^{2}$. The value of

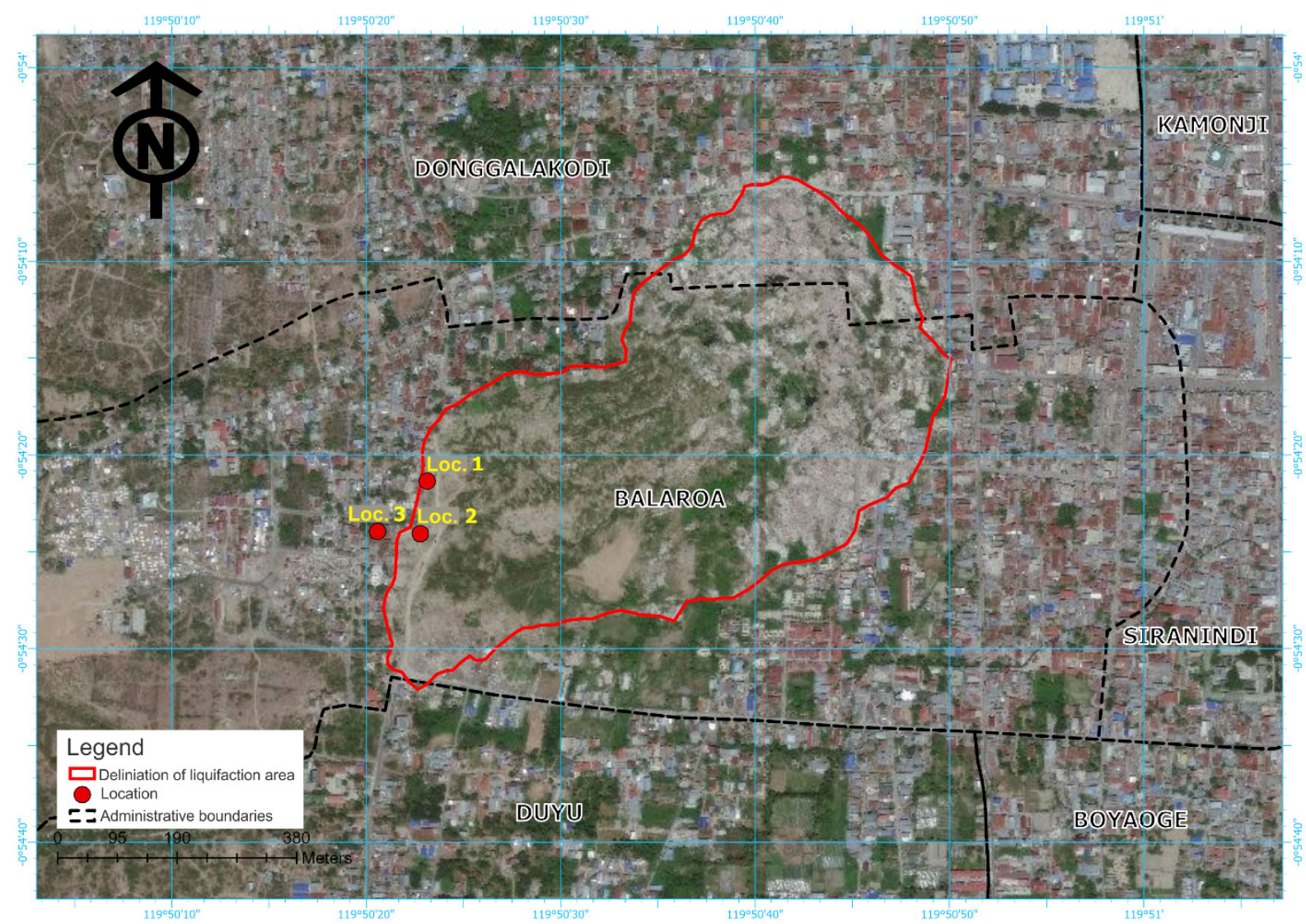

Figure 5: Map of research location 
Table 3: Parameter Input used in Slide 7.0

\begin{tabular}{|c|c|c|c|}
\hline Parameter & Loc. 1 & Loc. 2 & Loc. 3 \\
\hline Material Name & $\begin{array}{c}\text { Sandy } \\
\text { Silt }\end{array}$ & $\begin{array}{c}\text { Sandy } \\
\text { Silt }\end{array}$ & $\begin{array}{c}\text { Sandy } \\
\text { Clay }\end{array}$ \\
\hline $\begin{array}{c}\text { Unit Weight } \\
\left(\mathrm{kN} / \mathrm{m}^{3}\right)\end{array}$ & 15.3 & 16 & 15.6 \\
\hline $\mathrm{c}\left(\mathrm{kN} / \mathrm{m}^{2}\right)$ & 15 & 18 & 25 \\
\hline$\phi(\mathrm{o})$ & 27 & 38 & 25 \\
\hline Strength Type & $\begin{array}{c}\text { Mohr } \\
\text { Coulomb }\end{array}$ & $\begin{array}{c}\text { Mohr } \\
\text { Coulomb }\end{array}$ & $\begin{array}{c}\text { Mohr } \\
\text { Coulomb }\end{array}$ \\
\hline
\end{tabular}

moisture content for the three locations was location 1 at $8.11 \%$, location 2 at $8.3 \%$ and location 3 at $6.1 \%$.

The input parameters required in slope stability analysis using the Slide program can be seen in Table 3.

\section{RESULTS AND DISCUSSION}

\section{General description of the location}

The slope in the study area is between $20 \%-23 \%$. This slope was formed due to the earthquake on September 28th, 2018 which resulted in liquefaction.

The location of this study respectively has a slope height of $6.5 \mathrm{~m}$ at location 1 with a slope angle of $73^{\circ}$ (Figure 6.a), location 2 has a slope height of $12.32 \mathrm{~m}$ with a slope angle of $81^{\circ}$ (Figure 6.b) and location 3 has a slope height of $13.65 \mathrm{~m}$ with a slope angle of $84^{\circ}$ (Figure 6.c)

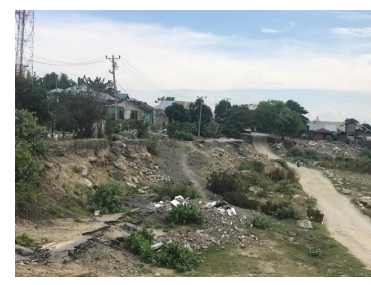

(a)

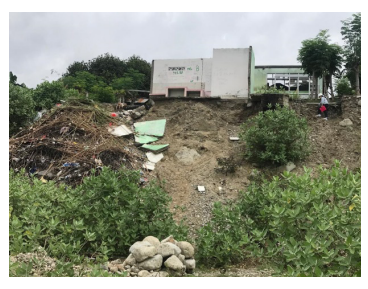

(b)

\section{Slope stability analysis using the limit equaibrium} method

In this study, the slope stablity analysis used the limit equalibrium method to obtain the safety factor values which were considered by the Ordinary method, the Bishop method and the Janbu method by modeling 3 existing slopes on the Balaroa road section that is prone to landslides. The analysis results can be seen in Table 4 for slope conditions before earthquake loads and Table 5 for slope conditions with earthquake loads. The results showed that the safety factor value of the existing slope at location 1 with a slope height of $6.5 \mathrm{~m}$ and the angle of 730 is 0.237 (Ordinary), 0.275 (Bishop) and 0.237 (Janbu). After being given an earthquake load of $0.3 \mathrm{~g}$, the safety factor value decreases by 0.078 (Ordinary), 0.127 (Bishop) and 0.078 (Janbu). The safety factor value of the existing slope at location 2 with a slope height of $12.32 \mathrm{~m}$ and angle of $81^{\circ}$ is 0.226 (Ordinary), 0.300 (Bishop) and 0.226 (Janbu), then after being given an earthquake load of $0.3 \mathrm{~g}$, the safety factor value decreseas by 0.022 (Ordinary), 0.109 (Bishop) and 0.019 (Janbu). The safety factor value on the existing slope of location 3 with a slope height of $13.65 \mathrm{~m}$ and an angle of $84^{\circ}$ is 0.147 (Ordinary), 0.168 (Bishop) and 0.146 (Janbu) then after being given an earthquake loads of $0.3 \mathrm{~g}$, the safety factor value decreases by 0.019 (Ordinary), 0.110 (Bishop) and 0.016 (Janbu). The appearance of the analysis of the existing slope modeling can be seen in Table 6 and Table 7.

Figure 6: The research locations a) Location 1, b) location 2 and c) location 3

Table 4: The simulation results of slope stability using the limit equalibrium method for condition without an earthquake load

\begin{tabular}{|c|c|c|c|c|c|c|}
\hline \multirow[b]{2}{*}{ Location } & \multirow[b]{2}{*}{ Lithology } & \multirow[b]{2}{*}{$\begin{array}{l}\text { Slope height } \\
\text { (m) }\end{array}$} & \multirow[b]{2}{*}{ Angle $\left({ }^{\circ}\right)$} & \multicolumn{3}{|c|}{ Safety Factor } \\
\hline & & & & $\begin{array}{l}\text { Ordinary } \\
\text { Method }\end{array}$ & Method & $\begin{array}{c}\text { Janbu Simpli- } \\
\square\end{array}$ \\
\hline 1 & Sandy Silt & 6.5 & 73 & 0.237 & 0.275 & 0.237 \\
\hline 2 & Sandy Silt & 12.32 & 81 & 0.226 & 0.300 & 0.226 \\
\hline 3 & Sandy Clay & 13.65 & 84 & 0.147 & 0.168 & 0.146 \\
\hline
\end{tabular}

Table 5: The simulation results of slope stability using the limit equalibrium method for condition with an earthquake load

\begin{tabular}{|c|c|c|c|c|c|c|}
\hline \multirow[b]{2}{*}{ Location } & \multirow[b]{2}{*}{ Lithology } & \multirow{2}{*}{$\begin{array}{l}\text { Slope height } \\
\text { (m) }\end{array}$} & \multirow[b]{2}{*}{ Angle $\left({ }^{\circ}\right)$} & \multicolumn{3}{|c|}{ Safety Factor } \\
\hline & & & & $\begin{array}{l}\text { Ordinary } \\
\text { Method }\end{array}$ & Method & $\begin{array}{r}\text { Janbu Simpli- } \\
\square\end{array}$ \\
\hline 1 & Sandy Silt & 6.5 & 73 & 0.078 & 0.127 & 0.078 \\
\hline 2 & Sandy Silt & 12.32 & 81 & 0.022 & 0.109 & 0.019 \\
\hline 3 & Sandy Clay & 13.65 & 84 & 0.019 & 0.110 & 0.016 \\
\hline
\end{tabular}


Table 6: Appearance of the analysis of the existing slope modeling without an earthquake load

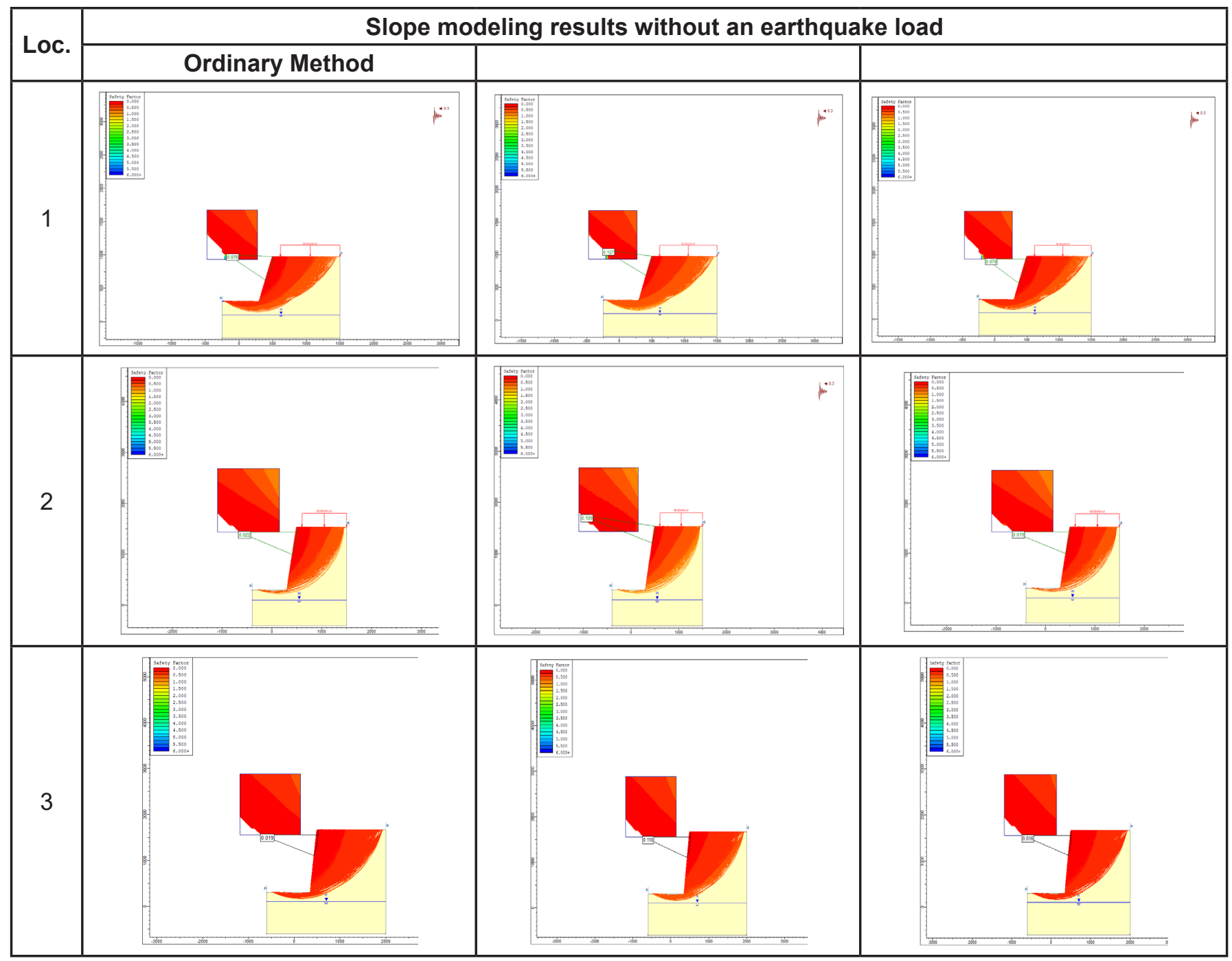

The results of slope stability analysis above explain that the existing slope conditions at location 1 , location 2 , and location 3 are in unsafe conditions both before and after an earthquake load with a velue of FS<1 [13].

The results show that slope condition on the Balaroa road section is unstable. The instability slope is due to the geometry of the high and steep slopes as well as the condition of Palu City which often occurs in earthquakes, therefore it needs to be treated. These results can be used as a reference for the government of Palu City to treat the slopes on the Balaroa road section, for there are still many residential areas on the slopes. The slope treatment either by making slopes or providing reinforcement to the slopes.

\section{CONCLUSION}

The Balaroa road section is located in Balaroa Village, West Palu sub district, Palu City. The researh area has a slope of $20 \%-23 \%$. The results of the slope stability analysis based on the limit equilibrium method for the three slope location points on the Balaroa road section, it was obtained the safety factor values that determined using the methods of Ordinary, the Bishop and Janbu as well is $\mathrm{FS}<1$, this indicates that the slope is in unsafe or in critical conditions, therefore, the government should take it into consideration by sloping the slopes or providing reinforcement to the slopes.

\section{ACKNOWLEDGMENTS}

The authors highly appreciate to the Tadulako University for funding this research in the form of research grant. Many thanks are also given to research team for their significant contribution during data collection in the research field. We also thank the head and the technicians of the Soil Mechanics Laboratory of Engineering Faculty for their assistance during the laboratory study.

\section{REFERENCES}

1. B.N.P.B (2018). Indeks Risiko Bencana Indonesia (IRBI) tahun 2018. Direktorat Pengurangan Risiko Bencana, BNPB.

2. BPS, K. P. (2019). Kecamatan Palu Barat dalam Angka. Kota Palu:, Badan pusat Statistik Kota Palu. 
Table 7: Appearance of the analysis of existing slope modeling with an earthquake load

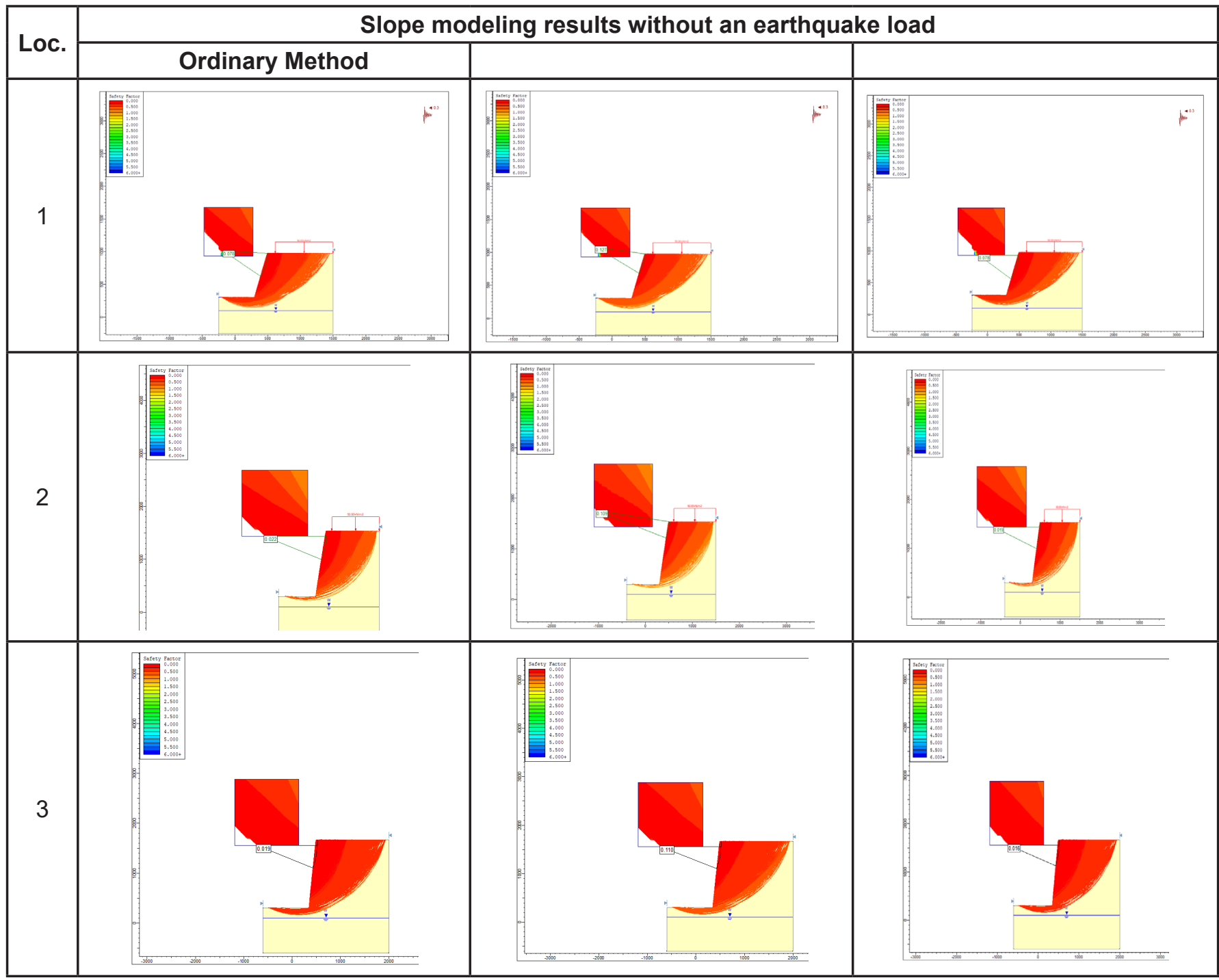

3. Pusgen. (2019). Investigasi Awal Longsor-Likuifaksi Geotechnical Extreme Events Reconnaissance (GEER) Akibat Gempa Palu 28 September 2018 (Geotechnical Repot on 2018 Palu-Donggala Earthquake); Pusat Penelitian dan Pengembangan Perumahan dan Pemukiman, Badan Penelitian dan Pengembangan, Kementerian Pekerjaan Umum dan Perumahan Rakyat.

4. https://www.humanitarianresponse.info/sites/www. humanitarianresponse.info/files/documents/files/ zrb_palu_dsk_alternatif_1_11des.pdf (diakses, 6 Oktober 2020, Pukul 09:53).

5. Ramadhani, S. (2011). Kondisi Seismisitas dan Dampaknya untuk Kota Palu. Jurnal Teknik Sipil Infrastruktur. 1(2), 111-119. http://jurnal.untad.ac.id/ jurnal/index.php/JTSI/article/view/692.

6. Sinarta, I.N., \& Basoka, I.W.A (2019). The Potential of Liquefaction Disasters Based on The Geological, CPT and Borehole Data at Southern Bali Island. Journal of Applied Engineering Science. 17(4), 642, 535 - 540. doi: 10.5937/jaes17-20794
7. Liu, H., Yang, T., \& Qin, Y. (2011). Analysis of Excavating High Slope by Means of Finite Element Method. ICTE, pp 1660-1665. https://ascelibrary.org/doi/ pdf/10.1061/41184\%28419\%29274.

8. Ramadhani, S., Rifa'l, A., Suryolelono, K. B., \& Wilopo, W. (2018). Slope Stability of Metamorphic Rocks Based on Rock Mass Classification at Poboya Gold Mine, Central of Sulawesi Province. International Review of Civil Engineering, Vol. 9 (No. 3): 91-97. https://doi.org/10.15866/irece.v9i3.13889

9. Widyaningrum, W. (2012). Penyelidikan Geologi Teknik Potensi Likuifaksi Daerah Palu, Provinsi Sulawesi Tengah, Kementrian Energi dan Sumber Daya Mineral, Badan Geologi, Pusat Sumber Daya Air Tanah dan Geologi Lingkungan.

10. de Vallejo, L. I., \& Ferrer, M. (2011). Geological Engineering. London, New York: CRC Press Taylor dan Francis Group. 
11. Ureel, S., \& Momayez, M. (2014). An Investigation of The Limit Equilibrium Method and Numerical Modeling for Rock Slope Stability Analysis. Rock Mechanics and Its Application in Civil, Mining, and Petroleum Engineering, 218-227. https://ascelibrary.org/doi/ abs/10.1061/9780784413395.025

12. Abramson, L. W., Lee, T. S., Sharma, S., \& Boyce, G. M. (2002). Slope Stability and Stabilization Methods (2nd ed ed.). New York: John Wiley \& Sons, Inc.

13. Hoek, E. (1991). When is a Design in Rock Engineering Acceptable. 3, hal. 1485-1497. Aachen: Proceedings of The 7th International Congress on Rock Mechanics.

14. SNI 8460. (2017). Persyaratan Perancangan Geoteknik. Jakarta: Badan Standarisasi Nasional.

15. Zhao, M., Liu, J., Chen, B., \& Liu, D. (2007). Variable weight combination forecasting model of slope deformation and instability. Rock and Soil Mechanics, 28(s1), hal. 553-557. China. http://en.cnki.com.cn/ Article_en/CJFDTotal-YTLX2007S1112.htm
16. Zhang, L., Liu, J., Fu, H., \& Guo, Z. (2011). Analysis on Dynamic Stabi https://ascelibrary.org/doi/ abs/10.1061/47628(407)24lity of Rock Slope in Seismic Area in Sichuan Province. ASCE, 217, 188-194.

17. Lu, L., Wang, Z., Huang, X., Zheng, B., \& Arai, K. (2014). Dynamic and Static Combination Analysis Method of Slope Stability Analysis during Earthquake. Mathematical Problems in Engineering. https://doi.org/10.1155/2014/573962

18. Luo, Y., Wang, Y., Fu, R., \& Liu, J. (2013). Study on Formation Mechanism of Liujiawan Landslide Tringgered by Wenchuan Earthquake. IACGE. https://ascelibrary.org/doi/abs/10.1061/9780784413128.009

19. Rocscience. (2018). Slide 7.0 Program. Toronto, Ontario, Canada: Rocscience Inc.

20. Pusgen. (2017). Peta Sumber dan Bahaya Gempa Indonesia 2017. Jakarta: Pusat Studi Gempa Nasional. 